\title{
The Relationships between Positive Thinking Skills, Academic Locus of Control and Grit in Adolescents*
}

\author{
İsmail Çelik ${ }^{1, *}$, Hakan Sarıçam² \\ ${ }^{1}$ Department of Educational Science, Faculty of Education, Agri Ibrahim Cecen University, Turkey \\ ${ }^{2}$ Department of Educational Science, Faculty of Education, Dumlupinar University, Kütahya, Turkey
}

Copyright $\odot 2018$ by authors, all rights reserved. Authors agree that this article remains permanently open access under the terms of the Creative Commons Attribution License 4.0 International License

\begin{abstract}
The main purpose of this study is to examine the possible relationships between academic locus of control, positive thinking skills and grit in high school students. The participants of the research are composed of 288 adolescents continuing their high school education from 4 different schools in Ağrl, Turkey which were selected with convenient sampling. 168 of the participants are male and 120 are female students. Pearson's moment correlation analysis was used for determining relations among variables, and multiple regression analysis was used to determine the regression coefficient of the variables on each other. Parametric tests were used, because the data showed a normal distribution. $\mathrm{p}<.01$ significance level criteria were taken. According to the findings, positive correlation between internal academic locus of control and positive thinking skills was found $(r=.54)$. A positive correlation was found between the internal academic locus of control and grit at $(r=.58)$. A positive correlation was found between positive thinking skills and grit $(r=.61)$. The internal academic locus of control, external academic locus of control and positive thinking skills explain the $50 \%$ of the grit's total variance. Based on this evidence, it can be said that the academic locus of control and positive thinking skills are important predictors for grit.
\end{abstract}

Keywords Locus of Control, Positive Thinking, Grit, Adolescent

\section{Introduction}

\subsection{Importance of the Study}

The concept of success, especially academic success, has been transformed into a basic need, not just a tool to describe students and children, by the education system, teachers and families. Because our education system is conductive to this; the student, who has to eliminate his or her peers to enter to a good high school, good university or a department, must be successful in this competitive environment. ERG [45] report stated that the socioeconomic status, number of siblings, parental education level, school types are effective to the student's success. In this context, in recent years, large investments have been made both as a state and as families to increase the academic success of the student. The increase (or be increased) in the schooling rate, the increase (or be increased) the classrooms and teachers, the continuous updating of the educational policies, the weekend courses, scholarships, distribution of free textbooks etc. are external factors that will increase the academic success. The fruits of the presentation of these opportunities within the country have begun to be received. As only the 8 th grade students in 2012 SBS were based upon, the number of the students who responded to all the questions was 677 , this number has increased to 4 thousand 742 in 2014-2015 and in the second term TEOG examination of 2015-2016 academic year 987 students have answered all the questions correctly; in the academic year of 2016-2017 TEOG-2, approximately 15 thousand students have answered all the questions. On the other hand, Turkey's average scores of mathematics and science literacy were below the average of OECD countries in PISA 2015 data $[12,13]$; even took the last places among the European countries. The impact of these external factors on academic achievement is undeniable, but the effects of the internal factors cannot be ignored. Nevertheless, the investments made to the external factors are costlier than the internal factors. The increase in the education expenditures among the OECD countries over the years [14] is not as bad as the PISA ranking. These differences between the success scores of local exam results (TEOG, YGS and LYS) and PISA achievement values reveal that the internal factors should be invested as well as the investments made to the external factors. In this study, 3 internal factors, which have a direct relation with the academic achievement, were considered as the academic locus of control $[15,16]$, positive thinking skills $[1,2,17,18,19]$ and the grit $[10$, 20]. 


\subsection{Literature Review}

As it was also implied by Aristotle; thinking is the most basic feature that is also accepted as the ability to understand relations between the events, so it distinguishes people from other living beings. By establishing bonds between the relationships that exist in his life, man gives meanings to the facts according to himself and demonstrates his behavior with the help of his ability to think. The positive thinking, seen as a reflection of positive psychology, is a mental attitude that makes thoughts occurred in the mind sufficient to become successful $[1,2]$. Through this attitude, the individual provides an internal balance and maintains a more upright stance against life [1]. Otherwise, not only condition of imbalance (alienation) but also negative thoughts arise in the individual and these negative thoughts also push the feelings and the behaviors of the individual to negation [3] and such individual can always look at events, facts, cases etc. in a negative way. However, the positive or negative origin of the thoughts can direct the life, the perspective on life, explanation of the facts, feelings and behaviors as it shapes the thoughts in these factors. In this interaction, the concept of locus of control must not be ignored.

The locus of control is defined as a dimension of personality as a perception that the responsibilities, which are oriented to the relationship between the individual's behaviors and their results, were directed to some objects $[4,5]$. In another definition, the locus of control is regarded as an output related to the repetition of the positive or negative consequences of the behavior in relation to the future expectations; separated into two as internal and external control. Thus, the locus of control is closely related with academic achievement [6], belief system [7], satisfaction with life [8] etc. As for the academic locus of control, it has similar contents as locus of control; it can be defined as a system for the academic achievement and performance of the individual. While the internal academic locus of control is directed toward the individual's own achievement, the external academic locus of control shows the success that came from a factor except the individual's own like luck, faith, teacher and friends. In other words, for the individuals with internal academic locus of control, it is the individual's oneself who brings the success and the external factors are necessary to achieve success in individuals with external academic locus of control [9]. With these expressions in mind, due to both the locus of control and the academic locus of control, our thoughts can transform to the different forms.

The grit is another predictor of academic achievement, just as academic control and positive thinking skills [10]. The grit is used as in a sense of strength, patience and persistence, which especially provides the individual to overcome the occurred challenges and improves the state of minds arising from long-term studies and aims to ensure the individual to be successful in all the conditions and occasions [11].

\subsection{Aim of the Study}

The main purpose of the study is to examine the possible relationships between the academic locus of control, positive thinking skills, and the grit in high school students. The answer to the following questions is searched to achieve this goal.

\subsection{Sub Problems}

- Is there a statistically significant difference in the level of positive thinking skills according to adolescents' academic locus of control type?

- Is there a statistically significant difference in the grit levels according to adolescents' academic locus of control type?

- Is there a statistically significant relationship between the positive thinking skills and the grit?

- Is a mediator variable that positive thinking skills in relationship between academic locus of control and grit?

\section{Method}

\subsection{Participants}

The participants of the research are composed of 288 adolescents continuing their high school education from 4 different schools in Agri which were selected with convenient sampling. 168 of the participants are male and 120 are female students. The ages of the participants ranged from 14 to 18 ; the average of the age is 15.81 $(\mathrm{SD}=7.83)$.

\subsection{Data Collection Tools}

Academic Locus of Control Scale - The Adolescent Form (ALCS-AF) The adolescent form of the scale was prepared by Sarıçam [21]. The scale consists of 17 items and 2 sub-dimensions; goodness of fit values were calculated as $\left(\chi^{2}=697.06, \mathrm{df}=392, \mathrm{RM}=.059, \mathrm{GFI}=.94, \mathrm{CFI}=.93\right.$, AGFI $=.92$, and SRMR $=.047$ ). The factor loadings of the scale are ranged from .32 to .88 ; Cronbach alpha internal consistency reliability coefficient was $.71,5$ for the internal academic locus of control subscale; and .81 for the external academic locus of control subscale were founded.

Positive Thinking Skills Scale (PTSS): PTSS was developed by Bekhet and Zauszniewski [1], and it was adapted to the Turkish culture by Akın et al. [22]. The eight items and one-dimension scale's goodness of fit values were calculated as $\left(\chi^{2}=25.66, \mathrm{df}=19\right.$, RMSEA $=0.35$, $\mathrm{NFI}=.99, \mathrm{NNFI}=.99, \mathrm{IFI}=1.00, \mathrm{RFI}=.98, \mathrm{CFI}=1.00$, GFI $=.98, \quad$ AGFI $=.96, \quad$ SRMR $=.027) . \quad$ The internal consistency reliability coefficient of the scale was found to be .87 .

Short Grit Scale (S-GS): The scale was developed by 
Duckworth and Quinn [23], and was adapted to Turkish by Sarıçam, Çelik and Oğuz [11]. Eight items and two sub-dimension scale's fit index values are $\left(\chi^{2} / \mathrm{df}=2.06\right.$, RMSEA $=.046, \quad \mathrm{CFI}=.95, \quad \mathrm{GFI}=.94, \quad$ AGFI $=.93$, $\mathrm{SRMR}=.047$ ) and item factor loads were ranged from .42 to .77. Cronbach alpha internal consistency reliability coefficients scale was calculated as .83 for the whole, .80 for the relations consistency sub-dimension and .71 for the persistence effort sub dimension.

\subsection{Procedure}

The application form for collecting information was applied by the researcher himself, except for the course duration and with voluntary participation. The participants were given 25 minutes to fill the form. The data obtained from the students were analyzed through computer statistical package program. Pearson's moment correlation analysis was used for the parametric analysis types and multiple regression analysis was used to determine the regression coefficient of the variables on each other since the data showed a normal distribution to determine the correlations. Confidence interval was based on $99 \%$, $(\mathrm{p}<.01$ as importance level).

\section{Results}

\subsection{Correlation Analysis}

Pearson moment product correlation analysis was performed to determine the relationship between the internal academic locus of control and positive thinking skills, and the results were shown in Table 1.

Table 1. Descriptive values, Cronbach alpha and correlation values

\begin{tabular}{|l|c|c|c|}
\hline \multicolumn{1}{|c|}{ Variables } & $\mathbf{1}$ & $\mathbf{2}$ & $\mathbf{3}$ \\
\hline 1. Internal academic locus of control & 1 & & \\
\hline 2. External academic locus of control & $-71 * *$ & 1 & \\
\hline 3. Positive thinking skills & $.54 * *$ & $-.44 * *$ & 1 \\
\hline Mean & 21.83 & 30.71 & 14.43 \\
\hline Standard deviation & 7.49 & 9.51 & 4.01 \\
\hline Cronbach alpha & .79 & .77 & .80 \\
\hline
\end{tabular}

When Table 1 was examined, a positive correlation was found between the internal academic locus of control and the positive thinking skills at the $\mathrm{p}<.01$ significance level $(r=.54)$. On the other hand, there was a negative correlation between the external academic correlation focus and the positive thinking skills at the $\mathrm{p}<.01$ significance level $(r=-.44)$. In other words, as the level of the internal academic locus of control increases, the level of the positive thinking skills increases or as the level of the external academic locus of control increases, the level of positive thinking skills decreases.

Pearson moment product correlation analysis was performed to determine the relationship between the internal academic locus of control and the positive thinking skills and the results were shown in Table 2.

Table 2. Descriptive values, Cronbach alpha and correlation values

\begin{tabular}{|l|c|c|c|}
\hline \multicolumn{1}{|c|}{ Variables } & $\mathbf{1}$ & $\mathbf{2}$ & $\mathbf{3}$ \\
\hline 1. Internal academic locus of control & 1 & & \\
\hline 2. External academic locus of control & $-71^{* *}$ & 1 & \\
\hline 3. Grit & $.58^{* *}$ & $-.53^{* *}$ & 1 \\
\hline Mean & 21.83 & 30.71 & 31.06 \\
\hline Standard deviation & 7.49 & 9.51 & 9.46 \\
\hline Cronbach alpha & .79 & .77 & .82 \\
\hline
\end{tabular}

$* * p<.01$

When Table 2 was examined, there was a positive correlation between the internal academic locus of control and the grit at $\mathrm{p}<.01$ significance level $(r=.58)$. On the other hand, a negative correlation was found between the external academic locus of control and the grit at the $p<.01$ significance level $(r=-.53)$. In other words, as the level of the internal academic locus of control increases, the grit increases, or as the level of the external academic locus of control increases, the level of the grit decreases.

Pearson moment product correlation analysis was performed to determine the relationship between the positive thinking skills and the grit and the results were shown in Table 3.

Table 3. Descriptive values, Cronbach alpha and correlation values

\begin{tabular}{|l|c|c|}
\hline \multicolumn{1}{|c|}{ Variables } & $\mathbf{1}$ & $\mathbf{2}$ \\
\hline 1. Positive thinking skills & 1 & \\
\hline 2. Grit & $.61^{* *}$ & 1 \\
\hline Mean & 14.43 & 31.06 \\
\hline Standard deviation & 4.01 & 9.46 \\
\hline Cronbach alpha & .80 & .82 \\
\hline
\end{tabular}

$* * \mathrm{p}<.01$

When the Table 3 was examined positive relationship between the positive thinking skills and the grit was found at $\mathrm{p}<.01$ significance level $(r=.61)$. In other words, the level of the grit increases as the level of the positive thinking skills increases.

\subsection{Regression Analysis}

Multiple regression analysis was applied for the third question; the grit was taken as dependent variable; the internal academic locus of control, the external academic locus of control and the positive thinking skills were taken as independent variable. The results are shown in Table 4. 
Table 4. Multiple regression analysis results for grit

\begin{tabular}{|c|c|c|c|c|c|c|}
\hline $\mathbf{V}$ & $\mathbf{R}$ & $\mathbf{R}^{2}$ & F & B & $t$ & $\mathbf{p}$ \\
\hline IALC & \multirow{3}{*}{.71} & \multirow{3}{*}{.50} & \multirow{3}{*}{$149.88^{* *}$} & .24 & 6.07 & .00 \\
\hline EALC & & & & -.21 & 5.46 & .00 \\
\hline PTS & & & & .26 & 7.23 & .00 \\
\hline
\end{tabular}

$* * \mathrm{p}<.01$, Dependent variable $=$ Grit, Independent variables $=$ internal academic locus of control (IALC), external academic locus of control (EALC), and positive thinking skills (PTS)

The regression model according to Table 4, seems statistically significant; the external locus of control is a negative explanatory variable for grit. The internal academic locus of control, external academic locus of control and positive thinking skills explain the $50 \%$ of the total variance of grit. Based on this data, it can be said that the academic locus of control and the positive thinking skills are important predictors for the grit.

\subsection{Mediation Analysis}

Multiple regression analysis (stepwise) was applied for the last question; the grit was taken as dependent variable; the internal academic locus of control, and the external academic locus of control were taken as independent variable and the positive thinking skills were taken as both independent variable and mediator variable. The results were shown in Figure 1.

A 4-step approach was used to test the mediation effect of positive thinking skills on the relationship between academic locus of control and grit. First, the direct effects of both internal $(\beta=.47, p<.01)$ and external $(\beta=-.45, p<.01)$ academic locus of control on positive thinking skills were found significant. Second, both the direct effects of internal $(\beta=.48, p<.01)$ and external $(\beta=-.46, p<.01)$ academic locus of control on grit were found significant as well. Third, the direct effect of positive thinking skills on grit was significant $(\beta=.56, p<.01)$. Finally, the Sobel test showed that the indirect effect of external and internal academic locus of control on grit via the mediator (i.e., positive thinking skills) was significant $(\beta=.24,-.21, \mathrm{p}<.01)$. These results supported partial mediation and indicated that academic locus of control has significant effects on grit through positive thinking skills.

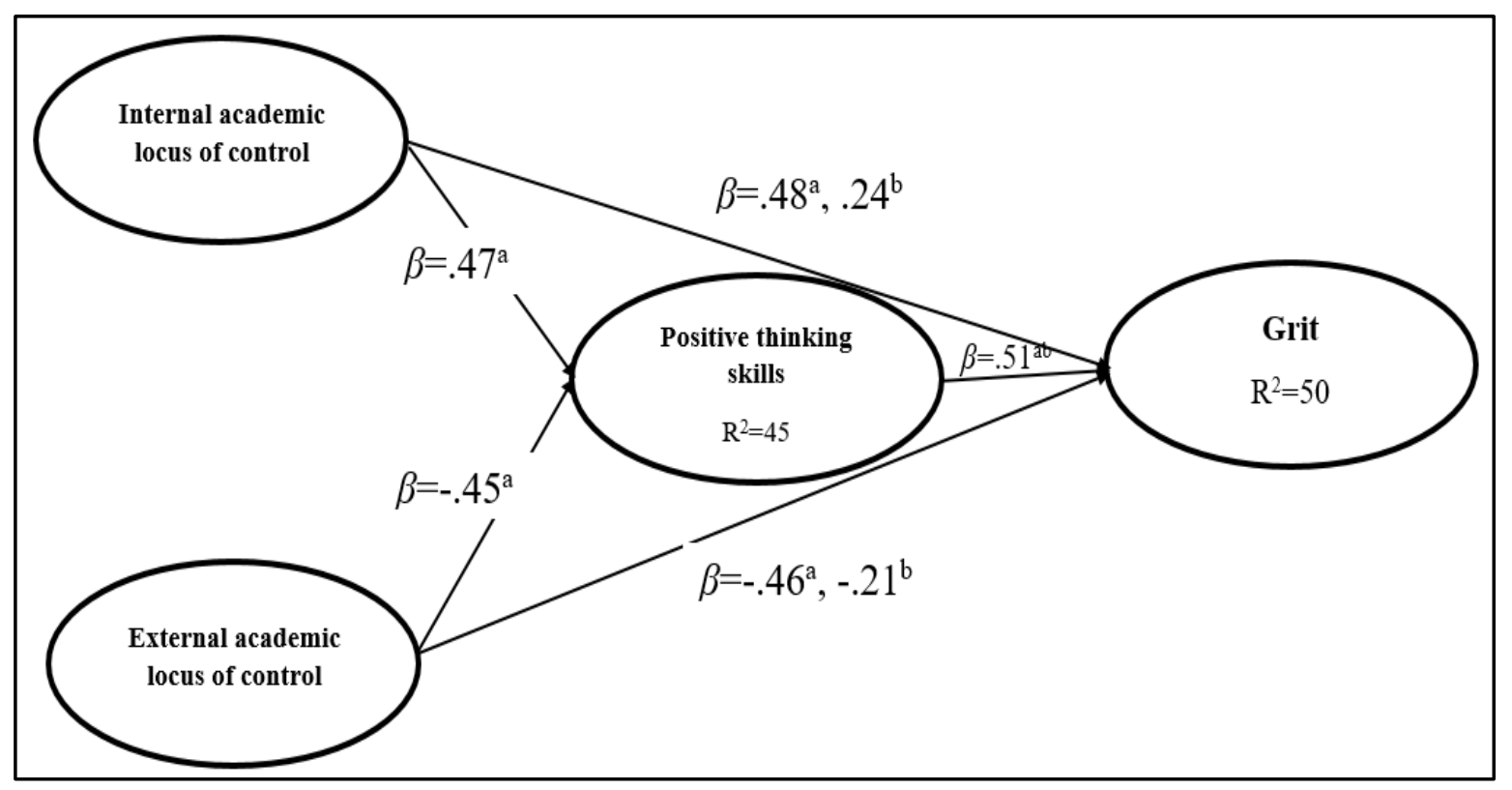

Figure 1. Mediation model for relationships between academic locus of control, positive thinking skills, and grit 


\section{Discussion and Conclusions}

The aim of this study was to further investigate the effects of internal and external academic locus of control on grit. Additionally, because the concept of positive thinking skills has been theorized to have possible effects on academic achievement and educational psychology, we aimed to test whether it would mediate the association between academic locus of control and grit. Sub-problems have been established to achieve this goal. In the first sub-problem, the relationship between positive thinking skills and the academic locus of control in high school students was discussed. There is a statistically significant relationship between the academic locus of control and the positive thinking skills according to the study findings. The positive thinking skills increase as the internal academic locus of control score increases and the positive thinking skills decrease as the external academic locus of control score increases. In other words, the positive thinking skills of the adolescents with the internal adolescent's locus of control are higher than the positive thinking skills of the adolescents with the external academic locus of control. When the literature was examined, there was no study directly examining the relationship between the positive thinking skills and the academic locus of control in adolescents. But Navabinejad, Babakhani and Karimi [24] have founded that the students with the internal locus of control had higher positive thinking skills when they were working with high school students. In addition, Oğuz and Sarıçam [5] have claimed that individuals with an internal locus of control had a better tendency to think critically. The locus of control is an important component of self-regulation mechanism $[4,25,26$,] and self-sufficiency $[27,28]$; is closely related to subjective well-being [29], or psychological well-being [30, 31]. Ramezani and Gholtash [32] have argued that individuals with self-control and internal locus of control are happier. On the other hand, it is claimed that subjective well-being and psychological well-being constitute positive thinking skills at the center of happiness and life satisfaction [33, 34, 35]. Hence, all the above studies indirectly support the current research findings.

In the second sub-problem, it was discussed whether there is a relationship between the grit in the high school students and the academic locus of control. There is a statistically significant relationship between the academic locus of control and the grit according to the study findings. As the internal academic locus of control increases, the grit level also increases. As the external academic locus of control increases, the grit decreases. In other words, the grit levels of adolescents with internal academic locus of control are higher than the grit levels of the adolescents with the external academic locus of control. When the literature was examined, there were no studies directly examining the relationship between the grit and the academic locus of control in adolescents. But Sarıçam [9] has found that individuals with an internal academic locus of control had higher levels of motivational persistence. Similarly, Karaman and Watson [36] have stated that there is a relationship between academic motivation and locus of control. The grit has long-term goals and a structure that is necessary for motivation $[37,38,39,40]$. Therefore, all the above studies support the current research findings.

In the third sub-problem of the study, it was examined whether there is a relation between the positive thinking skills and the grit in high school students. According to the study findings, there is a statistically statistically positive correlation between the grit and the positive thinking skills. As the students' positive thinking skill scores increase, their grit scores also increase. It can be say that students who think positively have more grit or the persevering students are thinking more positively. As far as we have examined, no studies have been found that directly examine the relationship between the positive thinking skills and the grit in adolescents. But according to claims of Duckworth, Quinn and Seligman, the persevering individuals have optimistic thoughts. In Borghans, Duckworth, Heckman and ter Weel [41] motivational, capacity, knowledge and opportunity-based personality model, what people want, can do, believe; determine how he thinks, behaves and feels. The persevering individual levels of happiness were high especially on long-term goals. In short, the individuals become happy if they want to be happy [42], Wyatt [43] has emphasized the importance of positive thinking in achieving goals. According to Gordeeva and Osin [17], the students who think positively are more successful in academic terms. Similarly, Sasson [44] said that thinking positively is needed as a key of success. When considered in this context, the above studies support the current research findings.

As a result, there are statistically significant relationships between the positive thinking, the academic locus of control and the grit. The positive thinking skills and the academic locus of control are significant predictors for grit in adolescents. Moreover, the academic locus of control types has important effects on grit owing to positive thinking skills. As the participants of the study were selected from the province of Agri, it is not right to make generalizations for all the adolescents as a result of the study. Therefore, expanding the study group in the future studies will be better in terms of the results of the study. The positive thinking skills, the academic locus of control and the grit variables are the internal factors for the academic success. In addition to these variables, the academic achievement levels, gender and grades can be tested with experimental and applied studies.

\section{REFERENCES}

[1] A. K. Bekhet \& A. Zauszniewski. Measuring use of positive thinking skills: Psychometric testing of a new scale. Western Journal of Nursing Research, 35(8) 1074-1093, 2013. 
[2] İ. Çelik \& H. Sarıçam. The relationships between academic locus of control, positive thinking skills and grit in high school students. (pp. 582-585). 26th International Conference on Educational Sciences, Antalya, 2017.

[3] D. Fanelli. The power of negative thinking. Science, 342, 68-69, 2013.

[4] J. B. Rotter. Generalized expectancies for internal versus external control of reinforcement. Psychological monographs: General and applied, 80(1), 1-28, 1966.

[5] A. Oğuz \& H. Sarıçam. The relationship between critical thinking disposition and locus of control in pre-service teachers. Journal of Education and Training Studies, 4(2), 182-192. doi:10.11114/jets.v4i2.1196, 2016.

[6] K. Diesterhaft \& K. Gerken. Self-concept and locus of control as related to achievement of junior high students. Journal of Psychoeducational Assessment, 1, 367-75, 1983.

[7] İ. Dağ. The relationship among paranormal beliefs, locus of control and psychopathology in a Turkish sample. Personality and Individual Differences, 26, 723-737, 1999

[8] İ. Çelik, H. Sarıçam, F. Bayoğlu \& M. Kacar. The relationship between positive thinking skills and life satisfaction in pre-service teachers. ERPA International Educational Sciences Congresses 6-8 June, Istanbul, 2014 , June.

[9] H. Sarıçam. Academic locus of control and motivational persistence: Structural equation modeling. Journal of Educational Sciences Research, 5(1), 79-92, Doi: http://dx.doi.org/10.12973/jesr. 2015.51.5, 2015.

[10] M. Reraki, İ. Çelik \& H. Sarıçam. Grit as a mediator of the relationship between motivation and academic achievement. Ozean Journal of Social Science, 8(1), 19-32, 2015.

[11] H. Sarıçam, İ. Çelik \& A. Oğuz. Kısa Azim (Sebat) Ölçeğinin Türkçeye uyarlanması: Geçerlik ve güvenirlik çalışması [Turkish adaptation of the Short Grit Scale (Grit-S): validity and reliability study]. Uluslararası Türkçe Edebiyat Kültür Eğitim (TEKE) Dergisi 5(2), 927-935, 2016.

[12] OECD, PISA 2015 Results (Volume II): Policies and Practices for Successful Schools, OECD Publishing, Paris. http://dx.doi.org/10.1787/9789264267510-en, 2016.

[13] OECD (2016b), PISA 2015 Results (Volume I): Excellence and Equity in Education, OECD Publishing, Paris. http://dx.doi.org/10.1787/9789264266490-en, 2016

[14] H. Egeli \& B. Hayrullahoğlu. Türkiye ve OECD ülkelerinde eğitim harcamalarının analizi [Analysis of Educational Expenditures in Turkey and OECD Countries]. Finans Politik \& Ekonomik Yorumlar, 51(593), 93-107, 2014.

[15] A. Akın. Achievement goals and academic locus of control: Structural equation modeling. Eurasian Journal of Educational Research, 38, 1-18. 2010.

[16] S. Harter. A new self-report scale of intrinsic versus extrinsic orientation in the classroom: Motivational and informational components. Developmental Psychology, 7(3), 300-312, 1981.

[17] T. O. Gordeeva \& E. N. Osin. Positive thinking as a factor of academic achievement in senior school students. Voprosy psikhologii, 1, 24-33, 2010.

[18] T. O. Gordeeva \& E. N. Osin. Optimistic attributional style as a predictor of well-being and performance in different academic settings: A new look at the problem. In: I. Brdar (Ed.), the human pursuit of well-being: A cultural approach (pp. 159-174). Dordrecht: London: New York: Springer, 2011.

[19] M. Panahi, H. Panahi \& H. Sobhani, Impacts of positive thinking skills up on happiness and academic performance of first level high school girls of Shirvan. International Academic Journal of Innovative Research, 3(6), 1-8, 2016.

[20] P. Tough. How children succeed; Grit, curiosity and the hidden power of character. Houghton Mifflin Harcourt, 2013.

[21] H. Sarıçam. Psychometric properties of the Academic Locus of Control Scale-Adolescent Form. Elementary Education Online, 13(4), 1135-1144, 2014

[22] A. Akın, M. A. Hamedoğlu, E. Yılmaz, Ü. Akın, M. A. Padır, E. Celik \& H. Sarıçam, The validity and reliability of the turkish version of the Positive Thinking Skills Scale. 2nd International Symposium on Chaos, Complexity and Leadership 17-19 December 2013, Ankara-Turkey.

[23] A. L. Duckworth \& P. D. Quinn. Development and validation of the Short Grit Scale (Grit-S). Journal of Personality Assessment, 91(2), 166-174, 2009.

[24] S. Navabinejad, V. Babakhani \& N. Karimi. The effectiveness of positive thinking skills on locus of control and controlling the test anxiety for female student of $3 \mathrm{rd}$ grade of high school. The Neuroscience Journal of Shefaye Khatam, 3(2) Suppl 1., 2014.

[25] A. L. Brown. Metacognition, executive control, self-regulation, and other more mysterious mechanisms. In Weinert F. E., Kluwe, R. H. (Eds.), Metacognition, motivation, and understanding (pp. 393-451). Hillsdale, New Jersey: Lawrence Erlbaum Associates, 1987.

[26] E. L. Deci \& R. M. Ryan. Intrinsic motivation and selfdetermination in human behavior. New York: Plenium Press, 1985 .

[27] A. Bandura. Self-efficacy: Toward a unifying theory of behavioral change. Psychological Review, 84, 191-215, 1977.

[28] J. Landine \& J. Stewart. Relationship between metacognition, motivation, locus of control, self-efficacy, and academic achievement. Canadian Journal of Counselling, 32(3), 200-212, 1998.

[29] E. Hamarta, Z. Özyeșil, M. E. Deniz \& B. Dilmaç. The prediction level of mindfulness and locus of control on subjective well-being. International Journal of Academic Research, 5(2), 145-150, 2013.

[30] D. P. Griffin. Locus of control and psychological well-being: Separating the measurement of internal and external constructs-A pilot study. EKU Libraries Research Award for Undergraduates. 2. http://encompass.eku.edu/ugra/2014/2014/2 2014.

[31] K. I. Vanderzee, B. P. Buunk \& R. Sanderman. Social support, locus of control, and psychological well-being. 
Journal of Applied Social Psychology, 27(20), 1842-1859, 1997.

[32] S. G. Ramezani \& A. Gholtash. The relationship between happiness, self-control and locus of control. Int J Educ Psychol Res, 1, 100-104, 2015.

[33] G. V. Caprara \& P. Steca. Affective and social self-regulatory efficacy beliefs as determinants of positive thinking and happiness. European Psychologist 10(4), 275-286, 2005. Doi: 10.1027/1016-9040.10.4.275

[34] H. Sarıçam, İ. Çelik, M. Kacar \& F. Bayoğlu, Üniversite ögrencilerinde üst bilişler ile mutluluk arasındaki ilişkinin incelenmesi. International Counseling and Education Conference (ICEC) - 2014, 26-28 May, Istanbul, 2014.

[35] H. Sarıçam \& İ. Çelik. Why positive thinking skills predict the life satisfaction? Meaning in life is an alternative view. (pp.3081-3084). 26th International Conference on Educational Sciences, Antalya, 2016.

[36] M. A. Karaman \& J. C. Watson. Examining associations among achievement motivation, locus of control, academic stress, and life satisfaction: A comparison of US and international undergraduate students. Personality and Individual Differences, 111, 106-110. 2017.

[37] A. L. Duckworth, C. Peterson, M. D. Matthews \& D. R Kelly. Grit: Grit and passion for long-term goals. Journal of Personality and Social Psychology, 92(6), 1087-1101, 2007.

[38] Y. J. Kim. The international comparison on the grit and achievement goal orientation of college students: focusing on the college students in Korea, China, and Japan. Advanced Science and Technology Letters, 119 10-13, 2015. http://dx.doi.org/10.14257/astl.2015.119.03

[39] J. P. Rojas. The relationships among creativity, grit, academic motivation, and academic success in college students. Theses and Dissertations--Educational, School, and Counseling Psychology. University of Kentucky. 2015. http://uknowledge.uky.edu/edp_etds/39

[40] K. Von Culin, E. Tsukayama \& A. L. Duckworth Unpacking grit: Motivational correlates of grit and passion for long-term goals. Journal of Positive Psychology, 9(4), 17, 2014.

[41] L. Borghans, A. L. Duckworth, J. J. Heckman \& B. ter Weel. The economics and psychology of personality traits. Journal of Human Resources, 43, 972-1059, 2008.

[42] R. Anthony. Beyond positive thinking: A no-nonsense formula for getting the results you want. Morgan James Publishing. 2004

[43] J. Wyatt. The path to positive thinking, positive thinking mastery for achieving goals and overcoming fears. E-Book Media Venture, 2012

[44] R. Sasson. Positive thinking-The key to success. Kindle Edition, 2014.

[45] Eğitim Reformu Girişimi-ERG, Türkiye eğitim sisteminde eşitlik ve akademik başarı araştırma raporu ve analiz. Available at http://kasaum.ankara.edu.tr/files/2013/02/ERGe\%C5\%9Fitl ikWEB.22.05.14.pdf, 2013
${ }^{*}$ Some part of this paper was presented as an oral presentation at 26th International Conference on Educational Sciences, Antalya. 